\title{
EFEKTIVITAS PENGGUNAAN METODE TUTOR SEBAYA (PEER TUTORING) UNTUK MENINGKATKAN MAHARAH QIRA'AH PADA PESERTA DIDIK KELAS XI IPA DI MADRASAH ALIYAH NEGERI 1 YOGYAKARTA
}

\author{
Temu Nurul Hasanah ${ }^{1}$ \\ ${ }^{1}$ Universitas Islam Negeri Sunan Kalijaga Yogyakarta, Indonesia \\ E-mail :temunurulhasanah846@gmail.com
}

Doi: $10.24252 / \mathrm{saa} . v 8 \mathrm{i} 2.15142$

\begin{abstract}
Penelitian ini membahas tentang bagaimana proses pembelajaran bahasa Arab dengan maharah qira'ah. Bertujuan untuk menjelaskan dan mendeskripsikan bagaimana proses pembelajaran dengan keterampilan membaca terjadi juga hasilnya. Penelitian ini termasuk dalam jenis penelitian kebahasaan dengan menitik beratkan pada pemahaman teks-teks arab berdasarkan kaidah-kaidah yang berlaku. Metode yang digunakan adalah metode kualitatif. Metode tutor sebaya adalah metode belajar mengajar dengan bantuan seorang peserta didik yang kompeten untuk menyalurkan ilmunya pada peserta didik lainnya. Pengumpulan data yang dilakukan untuk mengukur aktivitas belajar peserta didik yaitu dengan menggunakan observasi wawancara dengan pengampu mata pelajaran bahasa arab terkait problema-problema yang terjadi dalam hal keterampilan membaca. Penelitian menunjukkan bahwa peningkatan aktivitas belajar akan efektif jika dengan menghadirkan metode tuor sebaya. Kesimpulannya bahwa dengan penerapan metode tutor sebaya dapat mengefektifkan proses belajar dan hasil belajar siswa pada mata pelajaran bahasa Arab maharah qiraah
\end{abstract}

Kata kunci: Strategi Membaca; Metode Belajar Bahasa Arab

\section{PENDAHULUAN}

Pelaksanaan pembelajaran Bahasa Arab khususnya pada maharah Qira'ah seringkali mengalami hambatan. Salah satunya adalah lemahnya peserta didik dalam membaca tulisan Arab dalam bentuk wacana atau teks pendek. Adanya adagium takut salah membuat pembelajaran tidak berjalan semestinya. Oleh karenanya pendidik senantiasa melakukan upaya-upaya dan inovasi dalam pembelajaran Bahasa Arab sehingga adanya tujuan daripada pembelajaran tersebut akan tercapai secara maksimal.

Pada hakikatnya belajar itu bukan sekedar latihan akademik, tetapi merupakan aspek penting baik bagi individu maupun masyarakat. Bagi individu, belajar dapat memperoleh berbagai pengetahuann, sikap dan pengalaman, serta keterampilan yang didapatkan, tentang strategi untuk menjalankan perannya dalam kehidupan sehari-hari, maupun tentang sikap 
dan nilai-nilai, perilaku serta tindakan dalam kehidupan. ${ }^{1}$ Dibutuhkan sistem pengajaran tertentu untuk membelajarkan warisan kultural kepada generasi muda dan mempersiapkan mereka untuk mengambil alih peran produktif pendahulunya.

Begitupun dengan Bahasa, Bahasa memegang peranan penting dalam kehidupan. Manusia dari anak kecil sampai orang dewasa berkomunikasi dengan Bahasa. kenyataan ini disadari benar-benar. Oleh karena itu, Bahasa harus diajarkan kepada anak didik, hal ini harus disadari benar-benar, apalagi para pendidik umumnya dan para pendidik bidang studi pada khususnya. Dengan perkataan lain agar para peserta didik mempunyai kompetensi Bahasa (language competence) yang baik. Apabila seseorang mempunyai kompetensi Bahasa yang baik maka diharapkan dapat berkomunikasi dengan baik dan lancar, baik secara lisan atau tertulis. $^{2}$

Karena Bahasa merupakan kunci dari segala ilmu pengetahuan, maka apabila seseorang memegang kunci utama berarti ia telah memegang kunci jendela dunia. Bahkan dalam sebuah pidato pimpinan pondok modern Darussalam Gontor mengatakan bahwa bahasa merupakan mahkota. Sebab, segala pengetahuan dan peradaban semuanya terbahasakan bahkan sejarah tidak akan berwujud sejarah jikalau tidak ada bahasa serta seseorang dapat dimuliakan dengan bahasanya. Bahasa adalah satu-satunya kunci pembuka jalan bagi masa depan manusia dan peradaban dunia. Bahkan, seseorang dapat menjelajahi dan menguasai dunia dengan bahasa. $^{3}$

Membaca merupakan salah satu kemampuan keterampilan berbahasa yang harus dicapai oleh peserta didik. Keberhasilan peserta didik dalam mengikuti proses belajarmengajar di sekolah ditentukan oleh penguasaan mereka pada kemampuan membaca. Peserta didik yang tidak dapat membaca akan kesulitan mengikuti kegiatan pembelajaran untuk semua mata pelajaran termasuk pelajaran bahasa Arab. Oleh karena itu, pengajaran membaca perlu memperoleh perhatian serius, dan wacana membaca tidak boleh hanya dipandang sebagai batu loncatan bagi aktivitas berbicara dan menulis semata. Tujuan pengajaran membaca adalah mengembangkan kemampuan membaca peserta didik. Dengan demikian, tugas pendidik adalah meyakinkan proses pembelajaran membaca menjadi pengalaman menyenangkan bagi peserta didik.

\footnotetext{
${ }^{1}$ Gredler, Learning and Instruction (Teori dan Aplikasi) edisi keenam dialih bahasakan, Wibowo Tri, B.S, Jakarta: Kencana Prenada Media Group, 2011), h. 3.

2 Tarigan, Membaca Sebagai Suatu Keterampilan Berbahasa, (Bandung: Angkasa, 1990), h. 2.

3 Fathul Mujib, Rekonstruksi Pendidikan Bahasa Arab Dari Pendekatan Konvensional ke Integratif Humanis, (Yogyakarta : Pedagogia, 2010), h. Viii.
} 
Pentingnya pembelajaran Bahasa Arab ini hingga perlu dibuat berbagai pendekatan dan metode agar peserta didik lebih memahami dan menguasai Bahasa Arab. Maka dalam hal ini metode yang tepat digunakan adalah metode tutor sebaya (peer tutoring) karena dalam metode tersebut peserta didik akan lebih memahami apa yang diajarkan oleh pendidik, karena belajar dengan teman menjadikan peserta didik bebas untuk menyampaikan gagasangagasan dan pertanyaan-pertanyaan mengenai hal-hal yang belum mereka ketahun dan pahami. Metode tutor sebaya sebagai metode pembelajaran dimana sekelompok peserta didik yang telah tuntas terhadap bahan pelajaran, memberikan bantuan kepada siswa yang mengalami kesulitan dalam memahami bahan pelajaran yang dipelajarinya. ${ }^{4}$

Metode tutor sebaya adalah pembelajaran yang pelaksanaannya dengan membagi kelas dalam kelompok-kelompok kecil, yang sumber belajarnya bukan hanya peserta didik melainkan juga teman sebaya yang pandai dan cepat dalam menguasai suatu materi tertentu. ${ }^{5}$ Selain itu tutor sebaya dalam kelompok kecil dapat meningkatkan hasil belajar peserta didik dimana semua peserta didik aktif, antusias dalam melaksanakan tugas, semua perwakilan kelompok berani mengerjakan tugas didepan kelas, peserta didik berani bertanya dan respon peserta didik yang diajar sangat tinggi.

Metode pembelajaran tutor sebaya juga dapat meminimalisir dominasi pendidik dalam pembelajaran sebagaimana menjadi ciri khas pembelajaran konvensional. Berdasarkan pada fenomena pendidikan Bahasa Arab yang banyak terjadi pada era sekarang, juga pada beberapa permasalahan diatas maka dibutuhkan perubahan terhadap pendekatan, metode dan strategi pembelajaran Bahasa Arab. Oleh karenanya benang hitam yang penulis ambil dalam penelitian ini berfokus dengan judul bagaimana Efektivitas Metode Pembelajaran Tutor Sebaya Dalam Meningkatkan Maharah Qira'ah, diharapkan dapat berkontribusi dalam menjawab beberapa permasalahan yang terjadi dalam pendidikan Bahasa Arab di dunia dan Indonesia khususnya.

\section{METODOLOGI PENELITIAN}

Tulisan ini merupakan penelitian kualitatif. Sebagaimana yang sudah sering kita jumpai bahwa penelitian ini bertumpu pada analisisnya dan proses penyimpulan deduktif induktif serta pada analisis dinamika hubungan antar fenomena yang diamati, dengan menggunakan logika ilmiah. Hal ini bukan berarti bahwa pendekatan kualitatif sama sekali

\footnotetext{
${ }^{4}$ Suherman, Strategi Pembelajaran Matematika Kontemporer, (Bandung: UPI, 2003), h. 3.

${ }^{5} \mathrm{http}$ ://digilib.unnes.ac.id/gsdl/collect/ skripsi/archives/
} 
tidak menggunakan dukungan data kuantitatif akan tetapi penekanannya tidak pada pengujian hipotesis melainkan pada usaha menjawab pertanyaan penelitian melalui cara-cara berfikir formal dan argumentatif. ${ }^{6}$

Sumber data yang digunakan yaitu buku, artikel, dan beberapa sumber data atau informasi lainnya yang dianggap relevan dengan kajian. Teknik pengumpulan data yang digunakan adalah Contents analysis yaitu dengan melakukan observasi dan wawancara terkait tema. Observasi dilakukan untuk mengamati tutor sebaya dan peserta didik yang di tutori pada saat mengikuti pembelajaran membaca bahasa Arab. Penelitian dilaksanakan di Madrasah Aliyah Negeri 1 Yogyakarta kelas XI IPA di jalan C. Simanjuntak No.60, Terban, Kec Gondokusuman, Kota Yogyakarta, Daerah Istimewa Yogyakarta 552233. Subjek dari penelitian ini terdiri dari pendidik pada mata pelajaran Bahasa Arab saja dan dilakukan selepas proses pembelajaran membaca bahasa Arab.

Pemilihan subjek penelitian tersebut dikmaksudkan untuk memperoleh gambaran mangenai aspek apa yang dikaji dalam rumusan masalah. Dalam penelitian ini, aspek yang diungkap melalui wawancara dengan pendidik yaitu meminta masukan atau saran untuk kesuksesan pembelajaran selanjutnya. Adapun dalam wawancara dengan pendidik dijelaskan bagaimana beliau Bapak Yudistiro menerapakn tutor sebaya terhadap peserta didiknya yaitu dengan membungkusnya dalam wadah beberapa tugas muhadatsah yang di respon begitu antusias oleh peserta didik.

\section{HASIL DAN PEMBAHASAN}

\section{Kajian Pustaka}

kajian pustaka dilakukan untuk mengetahui sejauh mana penelitian yang telah dilakukan terhadap subjek bahasan. Juga untuk mengetahui perbedaan penelitian-penelitian terhadap penelitian yang sudah ada. Serta untuk memperlihatkan kontribusi penelitian yang akan dilakukan terhadap kelimuan di bidang kajian yang sama.

Adapun kajian pustaka penelitaian ini adalah: a). Penelitian yang dilakukan oleh Karima Nabila Fajri dalam Skripsinya yang berjudul “ Efektivitas Penggunaan Metode Tutor Sebaya (peer tutoring) dalam meningkatkan ketuntasan membaca Al-Qur'an pada pelajaran

\footnotetext{
${ }^{6}$ Azwar Saifuddin, Metode Penelitian, (Yogyakarta: Pustaka Belajar, 2011), h. 5.
} 
PAI-Bp di SMK Negeri 2 Karanganyar", dimana dalam penelitiannya mendeskripsikan dan menganalisis secara kritis mengenai proses pembelajaran dengan menggunakan metode tutpr sebaya (peer tutoring) pada pelajaran Pendidikan Agama Islam dan Budi Pekerti di SMK Negeri 2 Karanganyar. Dimana penelitiannya merupakan penelitian kulaitatif, dengan mengambil latar SMK Negeri 2 Karanganyar, pengumpulan data dilakukan dengan observasi, wawancara, observasi dan tes. ${ }^{7}$ b). Penelitian oleh Ikapti Puspasarani dalam jurnalnya yang berjudul "Efektifitas Metode Tutor Sebaya Untuk Meningkatkan Kemampuan Membaca Permulaan Anak Berkesulitan Belajar Membaca”, dimana dalam penelitiannya menggunakan kuantitatif dengan jenis penelitian eksperimen dengan pendekatan Single Subject Research (SSR). Yang bertujuan untuk mengetahui daripada pengaruh penerapan metode tutor sebaya tipe PALS dalam meningkatkan kemampuan membaca permulaan siswa berkesulitan belajar dengan subjek penelitian adalah peserta didik berkesulitan belajar spesifik kelas dasar 4, yakni subjek SMA. Pengumpulan data dilakukan dengan tes kemampuan membaca permulaan, observasi, dan dokumentasi membaca kelas dasar 4 di SDIT Harapan Ummat Purbalingga. ${ }^{8}$

\section{Maharah Qiraah}

Maharah qira'ah atau keterampilan membaca adalah salah satu keterampilan bahasa yang tidak hanya sekedar membunyikan huruf-huruf atau kata akan tetapi sebuah keterampilan yang melibatkan berbagai kerja akal dan pikiran. Membaca merupakan kegiatan yang meliputi semua bentuk-bentuk berpikir, memberi penilaian, memberi keputusan, dan mencari pemecahan masalah. ${ }^{9}$

Keterampilan membaca adalah identifikasi dan pemahaman dari semua jenis dan kecepatan dalam membaca, dan beberapa ditambahkan kedalam apa yang disebut membaca keras dan peserta didik dilatih untuk membaca bahasa asing dengan pemahaman tentang makna langsung tanpa upaya yang disengaja untuk menerjemahkan apa yang ada dalam teks Qira'ah ke bahasa ibu, dan itu dipahami oleh orang-orang yang pada cara bahwa kemudahan instruksi membaca, erat kaitannya pada pengucapan yang benar dan pemahaman teks, penggunaan struktur linguistik statistik secara lisan sangat penting bagi siswa untuk

${ }^{7}$ Karima Nabila Fajri, "Efektivitas Penggunaan Metode Tutor Sebaya (peer tutoring" dalam meningkatkan ketuntasan membaca Al-Qur'an pada pelajaran PAI-Bp di SMK Negeri 2 Karanganyar, Skripsi UIN Sunan kalijaga.

${ }^{8}$ Ikapti Pusparani, “Efektifitas Metode Tutor Sebaya Untuk Meningkatkan Kemampuan Membaca Permulaan Anak Berkesulitan Belajar Membaca”, Jurnal Widia Ortodidaktika Vol 7 No 3 Tahun 2018.

${ }^{9}$ Bisri Mustofa dkk, Metode dan Strategi Pembelajaran Bahasa Arab, ( Malang: UIN-Maliki Press, 2012), h.99. 
membaca dengan keras sebelum membaca dalam hati untuk membantu dia pada pemahaman yang baik tentang teks. ${ }^{10}$

Dalam buku Curiculum Development in Language Teaching ada beberapa metode yang dijelaskan yaitu: The Direct Method, The Reading Method, The Situational Method and Communicative Approach. ${ }^{11}$

Dalam hal apapun pilihan dari hasil memilih begitu penting, begitupun pemilihan suatu metode dan materi harus disesuaikan dengan tingkat kemampuan peserta didik, demi tercapainya pembelajaran yang baik sesuai target. Jika metode pembelajaran yang diterapakan tidak sesuai dengan tingkat kemampuan peserta didik, maka yang terjadi adalah pserta didik tidak nyaman dalam mengikuti proses pembelajaran.

Kriteria maharah qira'ah yang baik menurut Nashir Abdul Ghali dan Abdul Hamid Abdullah dalam bukunya yang berjudul Asaa AL Idad Al Kutubu At Ta'limiyah Li Ghairi An Nathiqin Bi Al Arabiyah yaitu:

1. Kesesuaian makharijul huruf dan dapat membedakannya

2. Menyesuaikan dengan kaedah makhraj

3. Memahai teks qira'ah secara sempurna dan rinci

4. Menyampaikan harakat huruf 'ain dengan penyampain yang sempurna

5. Mampu membedakan hamzah yang disambung dan hamzah yang diputus

6. Memelihara harakat yang panjang dan pendek

7. Menghindari terjadinya pergantian huruf yang mirip

8. Menghindari penambahan huruf

9. Menghindari penghapusan huruf

10. Memelihara wakaf yang sempurna yang berkaitan dengan teks qira'ah

11. Menganalisa secara mendasar gagasan utama teks qira'ah

12. Membedakan gagasan utama dan pendukung

13. Menghayati bacaan

14. Menganalisis dan mengkritisi

15. Menghilangkan keraguan dalam membaca. ${ }^{12}$

${ }^{10}$ Fattah Ali Yunus, Abdurrouf Syeikh, Al Maraji' Fi Ta'lim Al Lughah Al Arabiyah Li Al Janib, (Al Qahirah: Maktabah Wahab, 2003), h. 74.

${ }^{11}$ Jack C. Richards, Curiculum Development in Language Teaching, Tarjamah Nasir Bin Abdullah Al Ghali dan Shalih Bin Nashir As Syuaikhiroh, Thatwir Manahij Ta'lim Al Lughah. Tp: tt Nashir Abdul Hamid Nashir Abdul Ghali dan Abdul Hamid Abdullah dalam bukunya yang berjudul Asaa AL Idad Al Kutubu At Ta'limiyah Li Ghairi An Nathiqin Bi Al Arabiyah. (Al Qahirah: Dar An Nasr Li Thoba'ah Islamiyah, 1991), h. 25. 
Kemudian Agus Setiawan juga menambahkan level dalam membaca, yaitu: tingkat dasar adalah mulai mengerti sebua bahasa, tingkat inspeksi adalah menegrti sebuah buku dalam waktu sesingkat-singkatnya, tingkat analisis adalah mencerna isi buku, mengunyahnya dengan aktif dan tidak diberikan batasan waktu, serta tingkat pebandingan adalah membaca beberapa buku yang memiliki topik utama yang sama dan membandingkannya. ${ }^{13}$

\section{a). Jenis-Jenis Membaca}

Bila dilihat dari segi penyampainnya, membaca terbagi menjadi dua, yaitu:

1. Membaca nyaring (qiraahjahriyyah) yaitu kegiatan membaca dengan mengeluarkan suara atau kegiatan melafalkan lambang-lambang bunyi bahasa dengan suara yang cukup keras. ${ }^{14}$

2. Membaca senyap atau membaca dalam hati (qiraahshamitahah), yaitu membaca dengan melihat huruf dan memahami makna bacaan tanpa aktifitas organ bicara. ${ }^{15}$

\section{b). Strategi Pembelajaran Membaca}

Strategi atau tehnik pengajaran merupakan operasionalisasi metode. Karena itu tekhnik pengajaran adalah berupa rencana, aturan-aturan, langkah-langkah serta sarana yang dalam praktek akan diperankan dalam proses belajar mengajar di dalam kelas guna mencapai dan merealisasikan tujuan pembelajaran. Oleh sebab itu rencana, aturan dan langkah-langkah tersebut terkait erat dengan bingkai umumnya yaitu metode. ${ }^{16}$

Strategi juga menuntut kerja tim yang baik, sehingga dapat membantu peserta didik menjadi akrab dan saling berinteraksi dalam memhami ide cerita. Langkah-langkahnya bisa digambarkan dengan membagi menjadi beberapa kelompok, peserta didik diberi teks yang akan dipelajari, meminta peserta didik secara berkelompok meresume teks tersebut. ${ }^{17}$

\section{c). Kelebihan Maharah Qira'ah}

- Peserta didik terlatih memahami bacaan dengan analisis, tidak melalui terjemahan.

- Peserta didik menguasai kosakata dengan baik

${ }^{12}$ Nashir Abdul Ghali Abdul Hamid

13 Agu Setiawan, Baca Kilat: Kiat Membaca 1 Halaman per Detik, (Jakarta: Penerbit PT Gramedia Pustaka Utama, 2011), h. 11.

${ }^{14}$ Dalman, Mata Kuliah: Membaca. (Bandar Lampung: University Muhammadiyah Lampung Press, 2010), h. 48.

15 Radliyah Zaenuddin, Septi Gumiandari, Bisri Imam, Hasan Sefullah, Sumanta, Metodologi dan Strategi Alternatif Pembelajaran Bahasa Arab, (Cirebon: ST AIN Cirebon Press, 2005), h. 71.

16 Abd Hamid, Uril Baharuddin, Bisri mustofa, Pembelajaran Bahasa Arab: Pendekatan, Metode, Strategi dan Media, (Malang, 2008), h. 4.

${ }^{17}$ Radliyah Zaenuddin, h. 78. 
- Peserta didik memahami penggunaan tata bahasa

\section{d). Kekurangan Maharah Qiraah}

- Peserta didik lemah dalam keterampilan membaca nyaring

- Peserta didik tidak terampil dalam menyimak dan berbicara

- Peserta didik tkurang terampil dalam mengarang bebas

- Lemah dalam memahami teks yang berbeda. ${ }^{18}$

Keterampilan ini lebih tepat diterapkan pada kelas yang peserta didiknya homogen, yakni yang memiliki kemampuan standar. Karena akan menghabiskan waktu jika kemampuan kosakata dan kemampuan bahasa yang dimiliki minim. Dampaknya akan ada ketertinggalan bagi mereka yang tidak bisa membaca dan memahami teks sendiri.

\section{Tutor Sebaya (peer tutoring)}

Peer tutoring atau tutor sebaya merupakan sebagian dari coorperative learning atau belajar bersama. Dalam model ini peserta didik yang kurang mampu dibantu belajar oleh teman-temannya sendiri yang lebih mampu dalam suatu kelompok. Bentuknya adalah satu tutor membimbing beberapa teman dalam kelompok dari banyak pengalaman model peer tutoring lebih jalan daripada tutor oleh gurunya karena situasi ini peserta didik dengan tutornya lebhi dekat. Sedangkan jika dengan pendidiknya agak jauh. Cara pikir teman dan cara penjelasan teman biasanya lebih mudah ditangkap dan tidak menakutkan. ${ }^{19}$

Dalam metode peer tutoring ini peserta didik kemampuan lebih dalam suatu mata pelajaran dapat menjadi tutor bagi teman-temannya. Selanjutnya peserta didik dibagi kedalam kelompok-kelompok kecil da diminta untuk terlibat secara aktif dalam kegiatan diskusi. Sementara pendidik menempatkan diri sebagai pendamping fasilitator sekaligus teman belajar. Peran pendidik lebih memfasilitasi sebagai fasilitator, menyiapkan materi serta membantu dalam pemahaman materi.

\section{a). Kriteria Calon Tutor}

Calon tutor yang dipilih dari peserta didik juga meimilki kriteria, supaya nantinya dapat mencapai target yang digariskan, kriterianya sbb:

- Dapat diterima (disetujui) oleh peserta didik yang mendapat program perbaikan sehingga peserta didik tidak mempunyai rasa takut atau enggan untuk bertanya.

\footnotetext{
${ }^{18}$ Ahmad Fuad Effendi, Metodologi Pengajaran Bahasa Arab, (Malang: Misykat , 2009), h. 54. 148.

${ }^{19}$ Paul Suparno, Metodologi Belajar Fisika, (Yogyakarta: Penerbit Universitas Sanata Dharma, 2007), h.
} 
- Dapat menerangkan bahan perbaikan yang diperlakukan oleh peserta didik yang menerima program perbaikan.

- Tidak tinggi hati, kejam dan keras hati terhadap sesama kawan

- Mempunyai daya kreativitas yang cukup untuk memberikan bimbingan yaitu menerangkan pelajaran kepada kawannya. ${ }^{20}$

\section{b). Kelebihan Metode Tutor Sebaya}

Beberapa studi menemukan keuntungan dalam metode tutor sebaya atau peer tutoring.

- Tutor sebaya menghilangkan ketakutan yang sering disebabkan oleh perbedaan umur, status, dan latar belakang antara siswa dengan guru. Antar siswa lebih mudah kerjasama dan komunikasi.

- Lebih mungkin terjadi pembelajaran personal anatar teman dengan teman

- Si tutor sendiri akan mendapatkan pengertian lebih dalam dan menaikkan teman.

\section{c). Kelemahan Metode Tutor Sebaya}

Disamping ada keuntungan ada juga kelemahannya dari metode tutor sebaya ini, karena mau bagaimanapun kelebihan dan kelemahan selalu berdampingan, yaitu:

- siswa yang dibantu sering belajar kurang serius, karena hanya berhadapan dengan kawannya, sehingga hasilnya kurang memuaskan.

- Ada bebrapa anak yang malu bertanya, karena takut rahasianya diketahui oleh kawannya

- Perbedaan gender antar siswa juga menjadi penghambat dalam pelaksanaan metode tutor sebaya

- Bagai guru sangat sulit untuk menentukan tutor tang tepat bagi seseorng atau beberapa orang siswa yang harus dibimbing

- Tidak semua siswa yang pandai atau cepat waktu belajarnya dapat mengerjakannya kembali teman-temannya. ${ }^{21}$

\section{d). Langkah Dalam Metode Tutor Sebaya}

seperti yang di tulis oleh paul suparno, langkah-langkah metode tutor sebaya (peer tutoring) adalah sbb:

- Pendidik memberikan petunjuk pada tutor bagaimana mendekati temannya dan membantu temannya dalam hal bahan dan peralatan.

20 Syaiful Bahri Djamarah dan Azwan Zain, Strategi Belajar Mengajar, (Jakarta: Rhineka Cipta, 2010), h. 25 .

\footnotetext{
21 Syaiful Bahri Djamarah dan Azwan Zain, h. 27.
} 
- Pendidik mengubah tutor-tutor setelah beberapa minggu agar tidak selalu membimbing teman yang sama

- Pendidik membantu agar semua siswa dapat menjadi tutor sehingga mereka merasa dapat membantu teman belajar

- Pendidik sebaiknya bekerja dalam kelompok kecil campuran siswa berbagai kemampuan akan lebih baik.

- Pendidik selalu memonitor saat tutor atau siswa yang dipilih membutuhkan pertolongan dan bantuan

- Perencanaan yang matang dan kehati-hatian diperlukan. Kadang teman baik malah tidak jalan (dapat menghambat) karena lebih banyak membahas hal lain

- Tutor tidak mengetes temannya dengan orang tua murid. ${ }^{22}$

\section{Efektifitas Metode Tutor Sebaya}

Metode peer tutoring atau tutor sebaya dikatakan efektif diukur dari 2 (dua) hal yaitu proses dan hasil. Untuk proses dengan mengukur 7 (tujuh) efektifitas menurut Wortuba dan Wright, dan juga dengan mengukur keefektifan tutor, yaitu dengan mengacu pada kriteria tutor kemudian untk hasil dikatakan efektif apabila $85 \%$ dari jumlah peserta didik mendapatkan nilai minimal KKM yaitu pada angka 75 .

Jadi, dapat dikatakan metode tutor sebaya mendapat kategori efektif apabila dalam prosesnya memenuhi indikator dan kriteria tutor serta hasil belajarnya meningkat lebih tinggi dari KKM, yaitu $85 \%$.

\section{SIMPULAN}

Maka penelitian tersebut menghasilkan kesimpulan bahwa peserta didik Madrasah Aliyah Negeri 1 Yogyakarta kelas XI IPA telah mengikuti pembelajaran bahasa Arab khusunya keterampilan membaca dengan mengefetifkan metode tutor sebaya atau peer tutoring dengan baik. Dengan menggunakan metode pembelajaran tersebut peserta didik dilatih untuk bekerjasama dengan kelompoknya, saling menghargai, aktif, bertanggung jawab, dan mudah memahami materi. Peserta didik yang menjadi tutor maupun yang di tutori mengalami perubahan perilaku dari beberapa kali pertemuan. Kemampuan membaca pada peserta didik meningkat karena teman sebaya yang fokus mengajari temannya berkesulitan belajar tanpa harus membuat pendidik harus mengabaikan peserta didik lainnya.

${ }^{22}$ Moh. Uzer Usman dan Lilis Setiawati, Upaya Optimalisasi Kegiatan Belajar Mengajar, (Bandung: Remaja Rosdakarya, 1993), h. 96. 
Hal tersebut juga didukung oleh data hasil wawancara yang menunjukkan bahwa peserta didik menjadi lebih aktif, lebih bersemangat dan lebih antusias dalam mengikuti pelajaran bahasa Arab khusunya pada keterampilan membaca. Adapun efektifitasnya adalah peserta didik menguasai kosa kata dan percakapan bahasa Arab melalui isi teks Qira'ah sebagai pendukung keterampilan berbahasa Arab. Dan adapun perbedaan hasil belajar qira'ah peserta didik terdapat pada penguasaan teks qira'ah yang berkaitan dengan kaidah tata bahasa Arab yang sebagian besar peserta didik merasa kesulitan dalam menelaah kaidah tersebut.

\section{DAFTAR PUSTAKA}

Dalman, 2010, Mata Kuliah: Membaca. Bandar Lampung: University Muhammadiyah Lampung Press

Effendi, Ahamd Fuad. 2009, Metodologi Pengajaran Bahasa Arab, Malang: Misykat

Fajri, Nabila Karima. Efektivitas Penggunaan Metode Tutor Sebaya (Peer Tutoring) Dalam Meningkatkan Ketuntasan Membaca Al-Qur'an Pada pelajaran PAI-Bp di SMK Negeri 2 Karanganyar, Skripsi UIN Sunan kalijaga.

Gredler, Learning and Instruction, 2011. (Teori dan Aplikasi) edisi keenam dialih bahasakan, Tri Wibowo, B.S, Jakarta: Kencana Prenada Media Group

Hamid, Abd dkk, 2008, Pembelajaran Bahasa Arab: Pendekatan, Metode, Strategi dan Media, Malang.

Mustofa, Bisri dkk, 2012, Metode dan Strategi Pembelajaran Bahasa Arab, Malang: UINMaliki Press

Mujib, Fathul. 2010Rekonstruksi pendidikan Bahasa Arab Dari Pendekatan Konvensional Ke Integratif Humanis, Yogyakarta : Pedagogia

Pusparani, Ikapti. Efektifitas Metode Tutor Sebaya Untuk Meningkatkan Kemampuan Membaca Permulaan Anak Berkesulitan Belajar Membaca, Jurnal Widia Ortodidaktika Vol 7 No 3 Tahun 2018.

Richards, Jack C. 1991, Curiculum Development in Language Teaching, Tarjamah Nasir Bin Abdullah Al Ghali dan Shalih Bin Nashir As Syuaikhiroh, Thatwir Manahij Ta'lim Al Lughah. Tp: tt Nashir Abdul Hamid Nashir Abdul Ghali dan Abdul Hamid Abdullah dalam bukunya yang berjudul Asaa AL Idad Al Kutubu At Ta'limiyah Li Ghairi An Nathiqin Bi Al Arabiyah. Al Qahirah: Dar An Nasr Li Thoba'ah Islamiyah.

Suherman.2003, Strategi Pembelajaran Matematika Kontemporer, Bandung: UPI

Saifuddin, Azwar. 2011, Metode Penelitian, Yogyakarta: Pustaka Belajar

Setiawan, Agus. 2011, Baca Kilat: Kiat Membaca 1 Halaman per Detik, Jakarta: Penerbit PT Gramedia Pustaka Utama

Suparno, Paul. 2007, Metodologi Belajar Fisika, Yogyakarta: Penerbit Universitas Sanata Dharma

Setiawati, Lilis dan Moh. Uzer Usman, 1993, Upaya Optimalisasi Kegiatan Belajar Mengajar, Bandung: Remaja Rosdakarya.

Tarigan, 1990, Membaca Sebagai Suatu Keterampilan Berbahasa, Bandung: Angkasa

Yunus, Ali Fattah Abdurrouf Syeikh, 2003, Al Maraji' Fi Ta'lim Al Lughah Al Arabiyah Li Al Janib, Al Qahirah: Maktabah Wahab 
Zaenuddin, Radliyah dkk, 2005, Metodologi dan Strategi Alternatif Pembelajaran Bahasa Arab, Cirebon: STAIN Cirebon Press

Zain, Azwan dan Syaiful Bahri Djamarah, 2010, Strategi Belajar Mengajar, Jakarta: Rhineka Cipta.

http://digilib.unnes.ac.id/gsdl/collect/ skripsi/archives/ 